\title{
EFFECT OF DWARF AND NAKED NECK GENE ON THE EGG PRODUCTION PERFORMANCE IN TROPICS
}

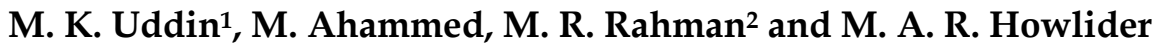 \\ Department of Poultry Science, Bangladesh Agricultural University \\ Mymensingh-2202, Bangladesh
}

\begin{abstract}
Cocks and pullets from each of 4 genotypes; Redbro (RbRb), Naked neck (NaNa), Redbro dwarf (Rbdw) and Naked neck dwarf (Nadw) were crossed reciprocally for egg production trial. Egg quality (egg weight, egg diameter, egg length, shell thickness, membrane thickness, membrane weight, shell weight, $\%$ of shell, yolk color score, albumen diameter, albumen height, yolk diameter and yolk weight) were compared among 4 genotypes. Daily feed intakes, almost related to respected body size were reduced in Rbdw and Nadw hens by 7.41 and $19.89 \%$ than in normal sized RbRb hens. The feed conversion and hen day egg production were highest in Rbdw, intermediate in $\mathrm{RbRb}$ and Nadw and lowest in NaNa. Naked neck (Na) and dwarf genotypes had favorable effect on egg fertility and hatchability. Parents in both $\mathrm{Na}$ and $\mathrm{dw}$ inheritance had favorable shell thickness, shell membrane weight $(\%)$, albumen height and diameter, yolk height and diameter, albumen weight and albumen weight (\%) and yolk weight, while NaNa had highest yolk weight (\%). Both egg weight and chick weight percent were highest in $\mathrm{RbRb} \times \mathrm{Rbdw}$ genotypes, followed by $\mathrm{RbRb}, \mathrm{RbRb} \times \mathrm{Nadw}, \mathrm{RbRb}$ x NaNa, Rbdw x RbRb, Rbdw, Rbdw x Nadw, Rbdw x NaNa, Nadw x RbRb, Nadw $x$ Rbdw, Nadw, Nadw x NaNa, NaNa x RbRb, NaNa x Rbdw, NaNa $x$ $\mathrm{Nadw}$ and $\mathrm{NaNa}$ respectively. Chick weight as percent of egg weight irrespective of genotype was simply the functions of egg weight.
\end{abstract}

Key Words : Dwarf gene, Naked neck gene, Egg production, Egg quality

\section{INTRODUCTION}

In Bangladesh poultry comprises mainly of Deshi chicken and ducks are rearing predominatly by scavenging system (UNDP/FAO, 1989). The small sized scavenging Deshi chickens weighing 1-2 kg are poor producer of both the meat and eggs (Huque, 1998). It will take long time to replace the scavenging poultry by commercial poultry industry. Thus, Bangladesh has a great potential to increase the poultry production by increasing small holders non-sophisticated rural units. Exotic improved breeds like White leghorn, Rhode Island Red, New Hampshire etc. of high yielding strains do not perform as per standard in the small holding units with poor management. The naked neck $(\mathrm{Na})$ chickens are well known for their higher heat tolerance than their fullfeathered counter parts. They also have higher total meat, breast meat and egg

\footnotetext{
${ }^{1}$ Laboratory of Applied Greenstock Science, Faculty of Bioresources, Mie University, Japan ${ }^{2}$ School of Agriculture and Rural Development, Bangladesh Open University, Gazipur, Bangladesh
} 
production (Merat, 1986; Howlider et al., 1995; Bairagi et al., 1992) than in full feathered birds. On the other hand, the dwarf birds are also heat and disease tolerant, more egg producer, need less maintenance and feed requirement than for the normal sized birds (Merat, 1986). Present study was conducted to know the effect of naked neck and dwarf genes on egg production performance.

\section{MATERIALS AND METHODS}

The entire experiment was conducted in an open-sided house of Bangladesh Agricultural University Poultry farm. A total of 20 cocks and 200 pullets were divided into 4 genotypes (Rbrb, Rbdw, NaNa and Nadw), each group consists of 5 cocks and 50 pullets. The birds were reared in cages for a period of 36 weeks from 25 to 65 weeks of age. During the whole experimental period all birds had an ad-libitum access to the balanced feed according to their age. Lighting period was maintained 16 hours daily with 8 hours darkness. Eggs were collected twice daily at 9 a.m. and 4 p.m. respectively. Thirty six eggs from each of the 4 genotypes were collected to observe egg quality characteristics. Experimental birds were allowed to cross according to the diagram given in Table 1.

Table 1. Crossing of basic parent lines

\begin{tabular}{|c|c|c|c|c|}
\hline Female Male & Redbro (RbRb) & $\begin{array}{l}\text { Redbro dwarf } \\
\quad(\text { Rbdw })\end{array}$ & $\begin{array}{c}\text { Naked neck } \\
\text { dwarf (Nadw) }\end{array}$ & $\begin{array}{l}\text { Local naked } \\
\text { neck (NaNa) }\end{array}$ \\
\hline Redbro (RbRb) & & $\mathrm{Rbdw} \times \mathrm{RbRb}$ & Nadw $\times$ RbRb & $\mathrm{NaNa} \times \mathrm{RbRb}$ \\
\hline Redbro dwarf (Rbdw) & $\mathrm{RbRb} \times \mathrm{Rbdw}$ & Rbdw $\times$ Rbdw & Nadw $\times$ Rbdw & $\mathrm{NaNa} \times \mathrm{Rbdw}$ \\
\hline Naked neck dwarf (Nadw) & $\mathrm{RbRb} \times \mathrm{Nadw}$ & Rbdw $\times$ Nadw & Nadw $\times$ Nadw & $\mathrm{NaNa} \times \mathrm{Nadw}$ \\
\hline Local naked neck (NaNa) & $\mathrm{RbRb} \times \mathrm{NaNa}$ & $\mathrm{Rbdw} \times \mathrm{NaNa}$ & $\mathrm{Nadw} \times \mathrm{NaNa}$ & $\mathrm{NaNa} \times \mathrm{NaNa}$ \\
\hline
\end{tabular}

\section{Determination of egg quality characteristics}

The production performances of hen of each groups was recorded based on the egg production, egg weight, feed intake, egg mass production and feed conversion ratio. The egg quality characteristics recorded as egg shell weight, shell dry weight, shell (\%), shell thickness and shell membrane thickness (Chowdhury, 1998), Haugh unit, albumen dry matter (\%), yolk color score, yolk index (Westey and Stadleman, 1959), fresh yolk (Chowdhury, 1988), and yolk dry matter (\%). Egg weight was measured with the help of egg weighing balance. The length and width were measured by a slide calipers and their mean values were recorded. The eggs were then carefully broken on a glass plate $(30 \mathrm{~cm}$ $\times 21 \mathrm{~cm}$ ) to measure the egg quality characteristics.

\section{Determination of egg shape index}

The egg shape index was determined by calculating the width and length of each egg using the formula derived by Reddy et al. (1965). Following is the formula of calculation :

Shape index $=$ Average width of egg/ Average length of egg. 


\section{Determination of albumen index}

The albumen index was determined by dividing the height of thick albumen by the width of thick albumen (Heiman and Carver, 1936). Following is the formula of calculation :

Albumen index = Average height of albumen/Average diameter of albumen.

Yolk index : The yolk index was calculated as the ratio of yolk height to yolk width without removing the yolk from albumen (Wesley and Staldeman, 1959).

Yolk index = Average height of yolk/Average width of yolk.

Haugh Unit (HU) : The unit was calculated for each egg by using the formula suggested by Haugh in 1937.

$\mathrm{HU}=100 \log (\mathrm{H}+7.57-1.7 \mathrm{~W} 0.37)$. Where $\mathrm{H}=$ height of thick albumen and $\mathrm{W}=\mathrm{egg}$ weight.

Yolk color : Yolk color was determined by comparing with the Roche Yolk Colour (RYC) Fan (F. Hoffman and La Roche Ltd., Switzerland).

\section{Shell thickness and shell membrane thickness}

After oven drying, shell thickness $(\mathrm{mm})$ and shell membrane thickness $(\mathrm{mm})$ were measured by means of shell thickness meter (Ogawa Shiki Co. Ltd., Tokyo, Japan).

\section{Breaking strength}

The breaking strength was determined by using a formula cited by Arad and Marder (1982). The breaking strength was calculated by the following formula :

Average breaking strength $=50.86 \times(\mathrm{EW})$ 0.915. Where EW = egg weight.

\section{Weight of different egg components}

The method outlined by Chowdhury (1998) was followed for partitioning different egg components. The yolk was separated carefully from the albumen with the help of a spatula and transferred to a bloating paper subsequently; the blotted yolk was transferred to a previously weighed petridish. The albumen was transferred to a previously weighed petridish by a spatula and reweighed. Precautions were taken to avoid rupture of yolk at all stages and also to keep the losses of yolk and albumen due to handling at minimum. Both raw albumen and yolk were transferred to an electronic oven and dried there at $105^{\circ} \mathrm{C}$ for 24 hours. On the following day, oven dried albumen and yolk were cooled in desiccators and weighed. These were dried up to constant weight and the final weight was noted. The shell of the broken eggs were rinsed and washed thoroughly in tap water keeping the membranes intact. The washed shells with membranes were immersed in a beaker of water (around 24 hours) for the removal of shell membranes. The shell and shell membranes were then oven dried separately at $105^{\circ} \mathrm{C}$ over night on glass petridishes. On the following day, oven dried shell and shell membranes were allowed to cool in desiccators and weighed. Drying of shell and shell membranes were counted in an oven until constant weight was obtained. Finally the weight of different components of the shell were determined as per the suggestion made by Chowdhury (1988). 


\section{Statistical analysis}

All the recorded and calculated data were analysed for ANOVA (Steel and Torrie, 1980) using a Completely Randomized Design (CRD). Significant differences to compare mean values of all the recorded and calculated parameters among the treatments were tasted by using Least Significant Differences (LSD). The data of egg production, egg quality characteristics of four genotypes chicken were analyzed using factorial experiment in a CRD.

\section{RESULTS AND DISCUSSION}

\section{Egg production performance}

Egg production performances of parental genotypes are shown in Table 2.

Table 2. Egg production performance of $\mathrm{RbRb}, \mathrm{Rbdw}, \mathrm{Nadw}$ and $\mathrm{NaNa}$

\begin{tabular}{l|c|c|c|c|c|cc}
\hline Genotype & $\begin{array}{c}\text { No. of } \\
\text { birds }\end{array}$ & $\begin{array}{c}\text { Age } \\
\text { (wks) }\end{array}$ & $\begin{array}{c}\text { Live wt. (gm) } \\
\text { At end of expt. }\end{array}$ & $\begin{array}{c}\text { Feed intake } \\
\text { g/bird/day }\end{array}$ & $\begin{array}{c}\text { Hen-day egg } \\
\text { production }\end{array}$ & $\begin{array}{c}\text { Hen-housed egg } \\
\text { production }\end{array}$ & FCR \\
\hline $\mathrm{RbRb}$ & 50 & $25-65$ & $3300 \pm 200$ & $135 \pm 20.50$ & $47.75 \pm 2.50$ & $40.50 \pm 1.50$ & 4.40 \\
$\mathrm{Rbdw}$ & 50 & $25-65$ & $2900 \pm 250$ & $125 \pm 7.50$ & $48.50 \pm 4.50$ & $45.50 \pm 40.25$ & 4.00 \\
$\mathrm{Nadw}$ & 50 & $25-65$ & $1530 \pm 450$ & $110 \pm 7.50$ & $42.50 \pm 2.70$ & $40.25 \pm 1.70$ & 4.52 \\
$\mathrm{NaNa}$ & 50 & $35-65$ & $950 \pm 300$ & $90 \pm 6.50$ & $18.75 \pm 3.20$ & $16.00 \pm 2.50$ & 10.36 \\
\hline
\end{tabular}

Daily feed intake of pullets was highest in $\mathrm{RbRb}$, intermediate in Rbdw and Nadw and lowest in $\mathrm{NaNa}$ genotypes respectively. In Rbdw and Nadw dwarf genotypes daily feed intakes were reduced by 7.41 and $19.89 \%$ compare to that of normal RbRb breeders. The feed intake was almost related to the body weights of different genotypes. The hen day egg production was hgighest in Rbdw followed by $\mathrm{RbRb}$, Nadw and $\mathrm{NaNa}$ respectively. Introgression of $\mathrm{dw}$ in $\mathrm{RbRb}$ breeders also increased egg production. The feed for egg production was highest in $\mathrm{Rbdw}$, medium in $\mathrm{RbRb}$ and $\mathrm{Nadw}$ and lowest in NaNa. Among the 4 genotypes improved FCR was found in $\mathrm{Rbdw}$ (4.00) and poor in $\mathrm{NaNa}(10.36)$. The beneficial effects of introgression of $d w$ gene in $R b R b$ on egg production and feed conversion for egg production recorded in Table 2 supports the findings of Yeasmin and Howlider (1998). They reported that the egg production was higher in dwarf broiler breeders than that of their normal counterparts. Decreased daily feed intake by Rbdw and $\mathrm{Nadw}$ genotypes than the normal RbRb breeders indicated the use of dwarf dams may substantially cut feed cost leading higher profitable of chick production. Decreased feed intake in birds with $d w$ inheritance is supported by many previous findings (Yeasmin and Howlider, 1998).

\section{Egg quality characteristics}

The data in Table 3 impress that the combination $\mathrm{Na}$ and $\mathrm{dw}$ had favorable effects on shell thickness, shell membrane weight (\%), albumen height and diameter, yolk height and diameter, albumen weight and albumen weight (\%) and yolk weight. The NaNa had highest yolk weight (\%) than the other 4 genotypes. The increased shell thickness, shell membrane weight (\%), albumen height and diameter, albumen weight and albumen 
weight (\%), and yolk were resulted for the combination of $\mathrm{Na}$ and $\mathrm{dw}$ genes were partially contradicted by Khoo and Beh (1977). They got no appreciable effect of dw gene on those egg quality characteristics. The difference between the results of this study and previous findings might have been arisen because of current study in Na was combined with dw gene.

Table 3. Egg quality characteristics of Redbro ( $\mathrm{Rb}), \mathrm{Rb} \times$ Dwarf ( $\mathrm{dw})$, Local naked neck $(\mathrm{Na})$ and Nadw genotypes

\begin{tabular}{|c|c|c|c|c|c|}
\hline \multirow[t]{2}{*}{ Parameter } & \multicolumn{4}{|c|}{ Genotypes } & \multirow{2}{*}{$\begin{array}{c}\begin{array}{c}\text { Level of } \\
\text { significance }\end{array} \\
G\end{array}$} \\
\hline & $\mathrm{RbRb}$ & Rbdw & $\mathrm{NaNa}$ & Nadw & \\
\hline Egg weight (g/egg) & $64.10^{\mathrm{a}}$ & $57.65^{b}$ & $40.55^{c}$ & $59.73 \mathrm{ab}$ & $* *$ \\
\hline Egg diameter (cm) & $4.38^{a}$ & $4.32^{\mathrm{a}}$ & $3.81^{b}$ & $4.15^{a}$ & $* *$ \\
\hline Egg length $(\mathrm{cm})$ & $5.69^{a}$ & $6.04^{\mathrm{a}}$ & $4.81^{b}$ & $6.24^{\mathrm{a}}$ & ** \\
\hline Egg shape index & $75.65^{a}$ & $71.52^{b}$ & $79.20^{a}$ & $66.51^{c}$ & $* *$ \\
\hline Shell thickness & $0.32^{b}$ & $0.32^{b}$ & $0.28^{a}$ & $0.34^{b}$ & * \\
\hline Membrane thickness (mm) & $0.04^{\mathrm{a}}$ & $0.04^{\mathrm{a}}$ & $0.03 \mathrm{~b}$ & $0.03 \mathrm{~b}$ & * \\
\hline Membrane weight (g/egg) & $0.20^{\mathrm{a}}$ & $0.20^{\mathrm{a}}$ & $0.10^{b}$ & $0.20^{\mathrm{a}}$ & $* *$ \\
\hline Membrane wt. \% of egg & $0.31^{b}$ & $0.35^{\mathrm{a}}$ & $0.25^{c}$ & $0.34 \mathrm{ab}$ & ** \\
\hline Shell weight (g/egg) & $5.33^{a}$ & $4.20^{b}$ & $3.10^{c}$ & $4.09 \mathrm{~b}$ & $* *$ \\
\hline Shell \% & $8.38^{a}$ & $7.33 \mathrm{~b}$ & $7.66 \mathrm{ab}$ & $7.05^{b}$ & * \\
\hline Yolk color score & $5.00^{\mathrm{ab}}$ & $5.50^{\mathrm{a}}$ & $4.25^{c}$ & $4.75 \mathrm{bc}$ & $* *$ \\
\hline Albumen diameter $(\mathrm{cm})$ & $7.78 \mathrm{ab}$ & $8.06^{a}$ & $6.91^{b}$ & $7.35 \mathrm{ab}$ & NS \\
\hline Albumen height (mm) & $5.73^{b}$ & $5.47 \mathrm{bc}$ & $5.00^{c}$ & $7.75^{\mathrm{a}}$ & ** \\
\hline Albumen index & $0.073 \mathrm{~b}$ & $0.067 \mathrm{c}$ & $0.072 \mathrm{~b}$ & $0.105^{a}$ & ** \\
\hline Yolk diameter (cm) & $4.65^{\mathrm{a}}$ & $4.38^{b}$ & $4.04^{\mathrm{c}}$ & $4.81^{\mathrm{a}}$ & NS \\
\hline Yolk height (mm) & $18.76^{b}$ & $18.65^{b}$ & $16.38^{c}$ & $19.93^{a}$ & ** \\
\hline Yolk index & $0.402^{\mathrm{ab}}$ & $0.426^{\mathrm{a}}$ & $0.406 \mathrm{ab}$ & $0.414^{\mathrm{a}}$ & $* *$ \\
\hline Albumen weight (g/egg) & $4.81^{\mathrm{a}}$ & $4.23^{a}$ & $2.68^{b}$ & $4.35^{\mathrm{a}}$ & $* *$ \\
\hline Albumen weight \% & $7.50^{\mathrm{a}}$ & $7.31^{\mathrm{a}}$ & $6.57 b$ & $7.29 \mathrm{a}$ & * \\
\hline Yolk weight (g/egg) & $10.41^{\mathrm{a}}$ & $10.38^{a}$ & $7.65^{b}$ & $10.03^{a}$ & ** \\
\hline Yolk weight \% & $16.25^{c}$ & $18.01 \mathrm{~b}$ & $18.87 \mathrm{a}$ & $16.79 c$ & ** \\
\hline Haugh unit & $72.6^{\mathrm{bc}}$ & $75.0^{\mathrm{b}}$ & $73.0 \mathrm{bc}$ & $88.2^{\mathrm{a}}$ & ** \\
\hline
\end{tabular}

NS $=$ Not significant, ${ }^{*} \mathrm{p}<0.05,{ }^{* *} \mathrm{p}<0.01$; the means having dissimilar superscript(s) significantly different

\section{Fertility and hatchability}

Both fertility and hatchability percent of eggs found highest in $\mathrm{NaNa}$ genotypes, followed by $\mathrm{Na} \times \mathrm{Nadw}$, NaNa $\times$ RbRb, NaNa x Rbdw, Nadw, Nadw x NaNa, Nadw $x$ 
$\mathrm{RbRb}, \mathrm{Nadw} \times \mathrm{Rbdw}, \mathrm{RbRb} \times \mathrm{NaNa}, \mathrm{RbRb} \times \mathrm{Nadw}, \mathrm{RbRb}, \mathrm{RbRb} \times \mathrm{Rbdw}, \mathrm{Rbdw} \times \mathrm{NaNa}$, $\mathrm{Rbdw} \times \mathrm{Nadw}, \mathrm{Rbdw} \times \mathrm{RbRb}$ and Rbdw genotypes, respectively. Slightly higher fertility and hatchability (Table 4) obtained in crossing genotypes with $\mathrm{Na}$ and $\mathrm{dw}$ inheritance was contradictory to the findings of Guillaume (1976); Merat (1984). They did not find any difference in fertility and hatchability which could be explained by the difference of $\mathrm{dw}$ inheritance. Higher fertility and hatchability of birds with the $\mathrm{Na}$ inheritance recorded was contradictory to the general believe of proper reproductive fitness of $\mathrm{Na}$ chicken. This finding clearly indicates that the local naked neck chicken of Bangladesh may have different reproductive fitness than naked neck of other origin.

Table 4. Fertility and hatchability of eggs of pure and crossbreds

\begin{tabular}{l|c|c}
\hline \multicolumn{1}{c|}{ Strains } & Fertility $(\%)$ & Hatchability (\%) \\
\hline Redbro & 74.87 & 80.25 \\
Redbro x Redbro dwarf & 76.24 & 80.50 \\
Redbro x Naked Neck dwarf & 75.98 & 80.65 \\
Redbro x Pure Naked Neck & 72.24 & 78.50 \\
Redbro dwarf x Redbro & 72.25 & 78.50 \\
Redbro dwarf & 74.25 & 81.00 \\
Redbro dwarf x Naked Neck Dwarf & 73.25 & 81.25 \\
Redbro dwarf x Pure Naked Neck & 76.36 & 82.50 \\
Naked Neck Dwarf x Redbro & 75.25 & 82.50 \\
Naked Neck Dwarf x Redbro dwarf & 75.40 & 83.60 \\
Naked Neck Dwarf & 78.00 & 83.75 \\
Naked Neck Dwarf x Pure Naked Neck & 78.25 & 87.50 \\
Naked Neck x Redbro & 72.25 & 86.50 \\
Naked Neck x Redbro dwarf & 75.25 & 86.75 \\
Naked Neck x Naked Neck Dwarf & 77.50 & 88.25 \\
Pure Naked Neck & 78.75 & 88.50 \\
\hline
\end{tabular}

\section{CONCLUSION}

According to the results obtained, the normal $x$ dwarf chicken had higher performance of hen day egg production than that of broiler parents. The hen day egg production of naked neck dwarf line (Nadw) was almost comparable to that of broiler breeder ( $\mathrm{RbRb})$. The fertility and hatchability of Na inheritance was higher in the hot humid climates which implies that it has the opportunity to genetic improvement of local chicken for hot humid climates.

\section{REFERENCES}

Arad, Z. and Marde, J. 1988. Differences in egg shell quality among the Sinia Bedouin fowl, the commercial white Leghorn and their crossbreds. British Poult. Sci., 23 : 107-112. 
Bairagi, M., Hamid, M. A., Islam, M. A. and Howlider, M. A. R. 1992. The effect of incorporation of naked neck gene from Bangladesh indigenous chicken to Rhode Island Red and White Leghorn on growth. Poult. Guide, 25 : 43-45.

Chowdhury, S. D. 1988. A method of partitioning egg components. Bangladesh J. Anim. Sci., 17 : 93-97.

FAO. 1989. FAO Statistics on Livestock Population. Asian Livest., 16(2) : 18-23.

Guillaume, J. 1976. The dwarfing gene (dw-); its effects on Anatomy, Physiology, Nutrition and Management. Its application in poultry industry. World's Poult. Sci. J., 32 : 285-303.

Heiman, V. and Carver, J. C. 1936. The albumen index as a physical measurement of observed egg quality. Poult. Sci., $28: 541-546$.

Howlider, M. A. R., Begum, F., Islam, M. S. and Wahid, M. A. 1995. Feathering and meat yield of full feathered and naked neck indigenous chicken of Bangladesh. J. Appl. Anim. Res., 8 : 191- 195.

Huque, Q. M. E. and Ukil, M. A. 1998. Energy contents of feeds consumed by scavenging chicken and duck in Bangladesh. Bangladesh J. Livest. Res.. 1-5(2) : 103-113.

Khoo, T. H. and Beh, B. L. 1977. Studies on the performance and nutritional requirements of dwarf and normal layers. Intl. Poult. Abst., 4 : 1978-1985.

Merat, P. 1986. Potential usefulness of Na (Naked -neck) gene in poultry production. World's Poult. Sci. J., 42 : 124-142.

Reddy, V. B., Sharma, P. L. M. and Varadarajulu, P. 1965. The effect of breed, preincubation storage time and egg weight on hatchability of poultry eggs. Indian Vet. J., $42: 438$.

Wesley, R. L. and Stadelman, W. J. 1959. Measurements of interior egg quality. Poult. Sci., 38 : 479-481.

Yeasmin, T., Howlider, M. A. R. 1998. Comparative physical features egg production and egg quality characteristics of Normal and dwarf indigenous (Deshi) hens of Bangladesh. J. Appl. Anim. Res. 13 : 191. 